A VIEW OF THE SEA 



\title{
A View of the Sea
}

\section{A Discussion between a Chief Engineer and an Oceanographer about the Machinery of the Ocean Circulation}

\author{
by \\ HENRY \\ STOMMEL
}


Copyright $@ 1987$ by Princeton University Press

Published by Princeton University Press, 41 William Street,

Princeton, New Jersey 08540

In the United Kingdom: Princeton University Press, Guildford, Surrey

All Rights Reserved

Library of Congress Cataloging in Publication Data will be found on the last printed page of this book

ISBN: 978-0-691-02431-8

This book has been composed in Linotron Century Schoolbook

Clothbound editions of Princeton University Press books are printed on acid-free paper, and binding materials are chosen for strength and durability. Paperbacks, although satisfactory for personal collections, are not usually suitable for library rebinding

Printed in the United States of America by Princeton University Press, Princeton, New Jersey 
To my wife and companion of thirty-seven years, Elizabeth 
